\title{
Does anterior chamber-associated immune deviation (ACAID) play a role in posterior lamellar keratoplasty? Case report of a splenectomized patient
}

\author{
Deniz $\operatorname{Hos}^{1,2^{*}}$, Friederike Schaub ${ }^{1}$ and Claus Cursiefen ${ }^{1,2}$
}

\begin{abstract}
Background: It has been shown experimentally in rodents that removal of the spleen leads to increased rejection of corneal allografts after corneal transplantation (keratoplasty).

Case presentation: Here, we report a unique case of a splenectomized patient with corneal endothelial dystrophy who underwent posterior lamellar keratoplasty. During follow-up of 4 years, we did not detect any signs of corneal allograft rejection.

Conclusions: Our report indicates that an intact spleen is not necessary for allograft acceptance after posterior lamellar keratoplasty. To the best of our knowledge, this is the first report of a splenectomized patient receiving a (lamellar) corneal transplant.
\end{abstract}

Keywords: Corneal transplantation, Keratoplasty, Anterior chamber-associated immune deviation, ACAID, Descemet membrane endothelial keratoplasty, DMEK

\section{Background}

Corneal transplantation (keratoplasty) is the most common and most successful form of transplantation worldwide. Graft survival rates are usually excellent with no need of HLA-matching, as the cornea belongs to the immune-privileged tissues of the body [1]. One condition that essentially contributes to this immune privilege is the so-called "anterior chamber-associated immune deviation" (ACAID), which leads to a systemic and antigen-specific suppression of immune responses when alloantigens are introduced into the anterior chamber [1]. Importantly, the induction of ACAID requires the participation of the spleen, and it has been shown experimentally in rodents that removal of the spleen prevents the development of ACAID and leads to increased rejection of corneal allografts after keratoplasty [2].

\footnotetext{
*Correspondence: deniz.hos@uk-koeln.de

'Department of Ophthalmology, University of Cologne, Faculty of Medicine and University Hospital Cologne, Cologne, Germany

${ }^{2}$ Center for Molecular Medicine Cologne (CMMK), University of Cologne,

Cologne, Germany
}

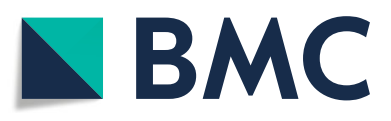

(c) The Author(s). 2019 Open Access This article is distributed under the terms of the Creative Commons Attribution 4.0 International License (http://creativecommons.org/licenses/by/4.0/), which permits unrestricted use, distribution, and

reproduction in any medium, provided you give appropriate credit to the original author(s) and the source, provide a link to the Creative Commons license, and indicate if changes were made. The Creative Commons Public Domain Dedication waiver (http://creativecommons.org/publicdomain/zero/1.0/) applies to the data made available in this article, unless otherwise stated. formed as full-thickness penetrating keratoplasty (PK), where all corneal layers were replaced by a donor cornea. Recently, novel lamellar grafting techniques have been developed and the most commonly used technique for posterior lamellar keratoplasty is Descemet membrane endothelial keratoplasty (DMEK), where only the diseased Descemet membrane and endothelium are replaced. DMEK has become the standard procedure for the treatment of endothelial disorders such as Fuchs corneal endothelial dystrophy (FCED) and shows superior visual rehabilitation and significantly lower risk of allograft rejection when compared to PK [3]. However, allograft rejection does occasionally occur after DMEK, especially during the first two postoperative years [4]. Whether the mechanisms of ACAID are also responsible for the low rates of graft rejection in DMEK, is currently unknown. Furthermore, it is unknown whether splenectomy prevents the potential development of ACAID and leads to allograft rejection after DMEK. 


\section{Case presentation}

Here, we report a unique case of a 76-year old female patient with FCED who underwent DMEK surgery. Several years before, the patient's spleen had to be removed because of an iatrogenic splenic injury during laparoscopy. The patient was generally immunocompetent and not unusually susceptible to infections. DMEK surgery without HLA-matching was performed without complications. Postoperatively, the patient received topical corticosteroids (prednisolone acetate 1\% 5 times daily), which was slowly tapered and stopped after 2 years, antibiotics (Ofloxacin 3 times daily for 2 weeks) and lubricants. The patient was followed regularly by slit-lamp biomicroscopy and visual acuity and endothelial cell densities were determined. During follow-up, we did not detect any signs of allograft rejection. Visual acuity was $20 / 25$ at 3 months and $20 / 20$ at 1,3 , and 4 years postoperatively. Donor endothelial cell density was 2553 cells $/ \mathrm{mm}^{2}$ preoperatively, 1779 cells $/ \mathrm{mm}^{2}$ at 3 months, 1609 cells $/ \mathrm{mm}^{2}$ at 1 year, 1377 cells $/ \mathrm{mm}^{2}$ at 3 years, and 1274 cells $/ \mathrm{mm}^{2}$ at 4 years postoperatively. Thus, endothelial cell loss rates were comparable to rates reported for eyes without rejection [5].

\section{Conclusions}

Experimentally, an intact spleen is a prerequisite for ACAID, and removal of the spleen in rodents leads to 90-100\% corneal allograft rejection after PK $[1,2]$. Whether this also holds true in humans and in lamellar keratoplasty, has not been shown so far. To our knowledge, this is the first report of a splenectomized patient receiving a (lamellar) corneal transplant. The fact that we did not observe any signs of allograft rejection indicates that an intact spleen is not necessary for allograft acceptance, at least after DMEK.

Interestingly, work from Hori and Streilein in mice have shown that graft rejection is significantly reduced when chimeric grafts (consisting of syngeneic epithelium and allogeneic stroma-endothelium) are used [6]. Such chimeric grafts might be protected from graft rejection not by an active suppression of immune responses but rather by immunological ignorance [7]. The situation of our patient who received a posterior lamellar allograft without transplantation of the anterior cornea has similarities with such a chimeric graft, although in DMEK only the Descemet membrane and not the additional stroma is of allogenic origin. Thus, it might be possible that the absence of graft rejection in our patient might be attributed not to ACAID but to immunological ignorance. In this context, it might be very interesting to evaluate whether chimeric grafts in splenectomized mice would result in graft rejection or not.

As mentioned, our patient received topical corticosteroids for the first 2 years after keratoplasty, which is known to significantly reduce the risk of allograft rejection after keratoplasty $[8,9]$. After termination of topical corticosteroids, the risk allograft rejection might be increased [9], although we did not observe any signs of allograft rejection in our patient so far. Nevertheless, additional follow-up will have to confirm that allograft rejection is not occurring in our patient, also considering that the risk of allograft rejection after DMEK is generally lower when compared to PK [3, 4].

\section{Abbreviations \\ ACAID: anterior chamber-associated immune deviation; DMEK: Descemet membrane endothelial keratoplasty;i FCED: Fuchs corneal endothelial dystrophy; HLA: human leucocyte antigen; PK: penetrating keratoplasty}

\section{Acknowledgements \\ Not applicable.}

\section{Funding}

Financial Support: German Research Foundation (DFG) FOR2240 "(Lymph) angiogenesis and Cellular Immunity in Inflammatory Diseases of the Eye": HO 5556/1-2 (to DH), Cu 47/9-1 (to CC; www.for2240.de); Center for Molecular Medicine Cologne (CMMC B3 to DH and CC; CMMC CAP 11 to DH); EU Arrest Blindness (to CC; www.arrestblindness.eu). The funding body had no role in the design of the study; collection, analysis, and interpretation of data; and in writing the manuscript

Availability of data and material

The datasets used and/or analyzed during the current study are available from the corresponding author on reasonable request.

\section{Authors' contributions}

$\mathrm{DH}, \mathrm{FS}$ and CC looked after the patient and collected the data. All authors read and approved the final manuscript.

Ethics approval and consent to participate

Not applicable.

\section{Consent for publication}

Written informed consent was obtained from the patient for publication. A copy of the written consent is available for review by the Editor of this journal.

\section{Competing interests}

The authors declare that they have no competing interests.

\section{Publisher's Note}

Springer Nature remains neutral with regard to jurisdictional claims in published maps and institutional affiliations.

Received: 8 February 2019 Accepted: 24 April 2019

Published online: 02 May 2019

\section{References}

1. Niederkorn JY. The immune privilege of corneal allografts. Transplantation. 1999:67(12):1503-8.

2. Niederkorn JY, Mellon J. Anterior chamber-associated immune deviation promotes corneal allograft survival. Invest Ophthalmol Vis Sci. 1996;37(13): 2700-7.

3. Anshu A, Price MO, Price FW, Jr. Risk of corneal transplant rejection significantly reduced with Descemet's membrane endothelial keratoplasty Ophthalmology 2012;119(3):536-540.

4. Hos D, Tuac O, Schaub F, Stanzel TP, Schrittenlocher S, Hellmich M, et al. Incidence and clinical course of immune reactions after Descemet membrane endothelial Keratoplasty: retrospective analysis of 1000 consecutive eyes. Ophthalmology. 2017;124(4):512-8. 
5. Schlogl A, Tourtas T, Kruse FE, Weller JM. Long-term clinical outcome after Descemet membrane endothelial Keratoplasty. Am J Ophthalmol. 2016;169: 218-26.

6. Hori J, Streilein JW. Role of recipient epithelium in promoting survival of orthotopic corneal allografts in mice. Invest Ophthalmol Vis Sci. 2001;42(3): 720-6.

7. Hori J, Streilein JW. Survival in high-risk eyes of epithelium-deprived orthotopic corneal allografts reconstituted in vitro with syngeneic epithelium. Invest Ophthalmol Vis Sci. 2003;44(2):658-64.

8. Nguyen NX, Seitz B, MartuS P, Langenbucher A, Cursiefen C. Long-term topical steroid treatment improves graft survival following normal-risk penetrating keratoplasty. Am J Ophthalmol. 2007;144(2):318-9.

9. Price MO, Scanameo A, Feng MT, Price FW, Jr. Descemet's membrane endothelial Keratoplasty: risk of immunologic rejection episodes after discontinuing topical corticosteroids. Ophthalmology 2016;123(6):1232-1236.

Ready to submit your research? Choose BMC and benefit from:

- fast, convenient online submission

- thorough peer review by experienced researchers in your field

- rapid publication on acceptance

- support for research data, including large and complex data types

- gold Open Access which fosters wider collaboration and increased citations

- maximum visibility for your research: over $100 \mathrm{M}$ website views per year

At BMC, research is always in progress.

Learn more biomedcentral.com/submissions 